Tyndale Bulletin 67.1 (2016) 63-86

\title{
THE ERASURE OF DISTINCTION: PAUL AND THE POLITICS OF DISHONOUR
}

\author{
J. R. Harrison \\ (jimh@scd.edu.au)
}

\begin{abstract}
Summary
The article investigates the deliberate erasure of inscriptional honours of two individuals in the first century: Augustus's 'friend', the infamous Gaius Cornelius Gallus, and the famous orator of Isthmia, Nikias. The public dishonouring of rivals by their enemies was common in antiquity. The author explores how this phenomenon illuminates Paul's conception of glory in Romans and his attack on boasting in oratorical performance in the Corinthian epistles. Paul sets forth a different understanding of honour based on the shame of the cross, God's election of the socially despised, and the elevation of the dishonoured in the Body of Christ.
\end{abstract}

\section{Introduction}

In antiquity the erasure of an inscription was a significant act of public dishonour to the honorand. ${ }^{1}$ It could be perpetrated by personal or family enemies of the honorand, or by rivals consumed with invidia ('envy', 'jealousy') over the honorand's civic distinction, or by political regimes redefining the past or, alternatively, reclaiming the past because of the despised actions, attitudes and ideology of the previous ruler(s). The phenomenon was widespread in antiquity but, surprisingly, it has only recently been studied in classical scholarship in

1 This damnatio memoriae should be distinguished from the removal of the original honorific inscriptions on public statues and their replacement by inscriptions in honour of a new honorand. See J. R. Harrison, "The Brothers as the "Glory of Christ" (2 Cor. 8:23): Paul's Doxa Terminology in Its Ancient Benefaction Context', NovT 52 (2010), 156-88, esp. 170-74. 
an extended way, ${ }^{2}$ and, so far as I am aware, it has been overlooked by New Testament scholars. The damnatio memoriae ('condemnation of memory') of figures of antiquity, perpetrated primarily through the destruction of their iconography and the erasure of their inscriptions, is well known, ${ }^{3}$ with Nero and Domitian being celebrated first-century examples. ${ }^{4}$ Sometimes the 'politics of dishonour' gripped ancient city states with particular intensity, spanning the original eulogy of the honorand, his subsequent damnatio memoriae by the new regime, and his restitution to political honour at a later period. ${ }^{5}$ The erasure of the public honour mentioned in the eulogistic inscription or of the honorand's name is the key ritual. There is little doubt, therefore, that the obliteration of distinction was deeply feared by the socially and politically powerful, as well as by their clients who basked in their patron's deflected honour.

Paul's refusal to be 'ashamed' of the 'foolishness' and 'weakness' of the gospel (Rom. 1:16; cf. Gal. 5:11; 1 Cor. 1:18-25) and his stance of honouring the social 'non-entities' in the Body of Christ (Rom. 12:16b; 1 Cor. 12:21-26; cf. 1:26-29) must have been deeply puzzling

2 E. R. Varner, Mutilation and Transformation: Damnatio Memoriae and Roman Imperial Portraiture (Leiden: Brill, 2004); H. I. Flower, The Art of Forgetting: Disgrace and Oblivion in Roman Political Culture (Chapel Hill, NC: University of North Carolina Press, 2006).

3 See Flower, The Art of Forgetting, s.v. Index, Erasures of inscriptions.

4 For examples of the erasure and non-erasure of Nero's inscriptions throughout the empire, see Flower, The Art of Forgetting, 337n45 and, more generally, 212-23. On damnatio memoriae and the iconography of Nero, see J. Pollini, 'Damnatio Memoriae in Stone: Two Portraits of Nero Recut to Vespasian in American Museums', AJA 88 (1984), 547-55; M. Bergmann and P. Zanker, "Damnatio Memoriae" Umgearbeitete Nero- und Domitiansporträts. Zur Ikonographie der flavischen Kaisar und des Nerva', Jahrbuch des deutschen archäologischen Instituts 96 (1981), 317-412; H. Born and K. Stemmler, Damnatio Memoriae: das Berliner Nero-Porträt (Mainz am Rhein: Sammlung Guttmann bei von Zabern, 1996), not seen by me. On the erasure of Domitian's inscriptions and the reworking of his statuary and iconography, see Flower, The Art of Forgetting, 240-62; Bergmann and Zanker, "Damnatio Memoriae". On Hadrian's removal of Nero's features from his bronze colossus and the statue's rededication to the Sun-god, see Scriptores Historiae Augustae, Hadrian 19.12-13.

5 Euphron of Sicyon was honoured with eulogistic inscriptions on stelae for his death in defending the democracy at Athens in 323/322 BC (W. Dittenberger, ed., Sylloge Inscriptionum Graecarum [=SIG ${ }^{3}$ ], 3rd ed., 4 vols. [Leipzig: Hirzel, 1915-1924], 310). However, the stelae were destroyed in $322 \mathrm{BC}$ by the oligarchic government, but were re-erected at Athens in $318 \mathrm{BC}$ when democratic government returned to the city for one year $\left(S I G^{3}\right.$ 317: 318-317 BC). See S. Wallace, 'History and Hindsight: The Importance of Euphron of Sikyon for the Athenian Democracy in 318/7', in The Age of the Successors and the Creation of the Hellenistic Kingdoms (323-276 BC), ed. H. Hauben and A. Meeus (Leuven: Peeters, 2014), 599-629. 
in an 'empire of honour'. ${ }^{6}$ Why extend honour to those who are by definition without honour? Why bother promulgating such a dishonourable message? Furthermore, in his personal relations, why didn't Paul simply erase the memory of the 'wrong-doer', the high status individual who had publicly opposed him at Corinth? ${ }^{7}$ Why did the apostle show genuine concern for that person's consolation as much as the hurt Corinthians (2 Cor. 2:5-8; cf. 7:12-13)? Why not consign the offender, whom Paul had rhetorically marginalised by refusing to

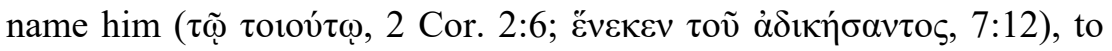
amicitiam renuntiare? The paradox of Paul's social attitudes in their ancient context runs deep.

This article explores two case studies in the 'politics of dishonour', one from the Latin West and the other from the Greek East. We will focus on (a) the inscription of Gaius Cornelius Gallus erected at Philae, as well as the erased inscription on his obelisk, relocated from Alexandria in Egypt to the Vatican Circus at Rome; and (b) the erased and relocated inscription of the orator Nikias at Isthmia. As noted, one inscription of each man has suffered erasures, pointing to Gallus's amicitiam renuntiare under Augustus and Nikias's (unexplained) slide into social dishonour. It will be argued that the 'politics of dishonour' in antiquity throws into sharp relief Paul's theology of 'glory' in Romans and exposes, from the perspective of his cruciform gospel, the bankruptcy of the Corinthian believers' preoccupation with rhetoric in assessing the power and wisdom of their leaders. In coming to grips with Paul's attitude to the ancient 'celebrity circuit' and the ephemeral nature of distinction, we will posit that Paul enunciates a radical alternative to the honour system of antiquity. The apostle argues that the protocols of 'honour' move from the base of the social pyramid up to its apex as opposed to the reverse direction in the case of the Mediterranean city-states. Thereby the 'status' games of antiquity, with the fall-out of 'dishonour' for the losers, are radically inverted.

\footnotetext{
6 On shame and honour language, see R. Jewett, 'Paul, Shame and Honor', in Paul in the Greco-Roman World, ed. J. P. Sampley (Harrisburg, PA: Trinity Press International, 2003), 551-74; J. R. Harrison, 'Paul and Ancient Civic Ethics: Redefining the Canon of Honour in the Graeco-Roman World', in Paul's GraecoRoman Context, ed. C. Breytenbach (Leuven: Peeters, 2015), 75-118.

7 See L. L. Welborn, An End to Enmity: Paul and the 'Wrongdoer' of Second Corinthians (Berlin: De Gruyter, 2011).
} 


\section{2. 'Republican' Boasting in the Early Reign of Augustus: the Case of Gaius Cornelius Gallus}

Stretching from the early Scipionic victories over their opponents and the naval victory of Dulius over the Carthaginians to the miliary achievements of the late republican generals, ${ }^{8}$ stylised Roman boasting in the victor who had achieved gloria ('glory') and virtus ('manliness') on behalf of the state and their house was de rigueur in the republican era. This was registered either in an inscription on a public monument, or in an epitaph on a sarcophagus, or at the mausoleum itself in the case of Augustus's Res Gestae. ${ }^{9}$ Rome's elogistic culture - where military and civic fame was a priceless commodity to be competed for and passed on to one's ancestors for eternity - had held its citizens spellbound while the great men of Rome fought for personal precedence until the Julian house, under Augustus, triumphed over its rivals in the acquisition of unprecedented glory. It should not surpise us, therefore, that Paul devoted so much attention to 'boasting' and 'glory' in the epistle to the Romans.

But the famous trilingual inscription of Gaius Cornelis Gallus reveals the dark underside of Roman eulogistic culture. This celebrated case of amicitiam renuntiare ('to renounce friendship') on the part of Augustus towards his trusted Egyptian prefect Gallus and the subsequent erasure of Gallus's inscriptions highlights the rituals of 'honour' and 'dishonour' at the heart of Julio-Claudian rule and how easily they could go astray. It provides us with a convenient litmus test for assessing how Paul advises Roman believers about living in an honour-driven society. The apostle was well aware that rivalries over honour could destroy unity in Christ (Rom. 12:10b), lead to attitudes of social superiority and personal conceit (12:16), or culminate disastrously for believers by their acting with dishonour towards the politically and socially powerful (13:7b). What, then, does the episode

8 On the inscriptions of the Scipios, Duilius and the late republicans, see J. R. Harrison, Paul and the Imperial Authorities at Thessalonica and Rome: A Study in the Conflict of Ideology (Tübingen: Mohr Siebeck, 2011), 219-25; R. Ridley, The Emperor's Retrospect: Augustus Res Gestae in Epigraphy, Historiography and Commentary (Leuven: Peeters, 2003), 58-61.

9 On the Res Gestae, see J. R. Harrison, 'Augustan Rome and the Body of Christ: A Comparison of the Social Vision of the Res Gestae and Paul's Letter to the Romans', HTR 106.1 (2013), 1-36. 
of Gaius Cornelius Gallus teach us about the early 'empire of honour' in which Paul writes?

\subsection{Gaius Cornelius Gallus and the Traditional Roman Quest for Glory}

The crisis precipitated by Gaius Cornelius Gallus (70-26 BC) highlights the increasing sensitivity of the Augustus and the Senate to independent careerists. ${ }^{10}$ The grievance was that careerists like Gallus aspired to the style of leadership characteristic of the nobiles ('nobles') of the past, without sufficient reference to the new military and patronal dominance of the house of Caesar in the present. In $30 \mathrm{BC}$ Augustus had appointed Gallus as the first praefectus of the new Roman province of Egypt. At the command of Augustus, Gallus built the Forum Julium at Alexandria and duly dedicated it to his patron and friend, Augustus, and his son, Tiberius. ${ }^{11}$ Moreover, as a professional poet, Gallus also wrote an epigram in honour of Augustus's forthcoming victorious return to Rome in 29 BC. ${ }^{12}$ So far his career reflected the gratitude of a grateful cliens and amicus to his patron.

However, upon crushing local rebellions and receiving Ethiopia into Roman protection, Gallus erected a boastful trilingual inscription on 15th April $29 \mathrm{BC}$ at Philae, celebrating the feats of his unprecedented expedition in the grand style of the Scipionic sarcophagus inscriptions (elogia) and the inscription of the Roman general Duilius, the victor over Carthage. The translation of the Latin text, as opposed to the Greek text, is cited below, because the likelihood is that it came from

10 On Gallus's career, see J.-P. Boucher, Gaius Cornélius Gallus (Paris: Bibliothèque de la Faculté des Lettres de Lyon, 1996), 5-65.

11 D. C. Braund, Augustus to Nero: A Sourcebook on Roman History 31BC-AD 68 (London: Croom Helm, 1985), §424.

12 Braund, Augustus to Nero, §426. See, however, R. D. Anderson, P. J. Parsons and R. G. M. Nisbet, 'Elegiacs by Gallus from QASR IBRIM', JRS 69 (1979), 125-55, which argues that Gallus's epigram refers to Julius Caesar, not Augustus, and is datable to c. 45-44 BC; cf. J. Fairweather, 'The 'Gallus Papyrus': A New Interpretation', CQ 34.1 (1984), 167-74. But the honorific sentiments of the epigram are consonant with the honorific sentiments of the $30 \mathrm{BC}$ inscription and thus point to the epigram being written a few months later. Gallus's epigram (P. Qasr Ibrîm 1 ll. 2-5 [1st century BC, Egypt]) is set out below:

My fate, Caesar, will then be sweet to me, when you

will be the greatest part of Roman history

and when I read that after your return temples of many gods

are richer, hung with your spoils. 
Gallus's own hand, as the elegant literary structure of the Latin demonstrates. ${ }^{13}$

Gaius Cornelius Gallus, son of Gnaeus, Roman eques, first (primus) prefect of Alexandria and Egypt after the defeat of the kings by Caesar, son of a god, put down the uprising of the Thebaid in 15 days, in which he defeated the army, having won two pitched battles and taken five cities by storm - Boresis, Coptus, Ceramice, Diospolis Magna and Ophieion; the leaders of these uprisings were captured and our army was led beyond the (first) cataract of the Nile, whither neither the arms of the Roman people nor those of the kings of Egypt had previously advanced; the Thebaid, a source of fear for all kings alike, was subdued and envoys of the king of the Ethiopians were given audience at Philae and that king was received into protection, and a ruler of the Ethiopian Triakontaschoenus was established; he made this dedication to the ancestral gods and to the Nile, his helper. ${ }^{14}$

This inscription was accompanied by further inscriptions being inscribed on the pyramids, in addition to his statues being erected throughout Egypt. Augustus reacted immediately, recalling Gallus from his post and renouncing his friendship, with the result that Gallus committed suicide in 26 BC (Suetonius, Augustus 66:1-2; Lives of the Grammarians 16; Dio, Roman History 53:24:1; cf. Ovid, Amores 3:9:61; Tristia 2:445-446).

What was wrong with the tenor of the inscription? Gallus did not mention that he was sponsored by Augustus, which the inscriptions of Augustus's senatorial, equestrian and military protégés were very careful to do. ${ }^{15}$ The outstanding accomplishments of Roman nobles

13 F. Hoffmann et al., eds., Die dreisprachige Stele des C. Cornelius Gallus: Übersetzung und Kommentar (Berlin: De Gruyter, 2009), 45-118. Hoffmann translates and comments on the hieroglyphic version of the inscription, demonstrating how the Egyptian priests depicted Gallus with traditional Egyptian motifs. This is reinforced by the iconographic depiction of Gallus as a horseman fighting against an enemy soldier in the upper part of the stele, identified in the cartouches as the chosen agent of the new ruler of the country, Romaios or Rome (31-40, esp. 32-33). The depiction is indebted to Egyptian iconographic renderings of the early pharaonic and later Ptolomaic conquests of the enemy (26-31). On the elegant literary structure of the Latin inscription, see 121-26.

14 Braund, Augustus to Nero, $\S 425$ (CIL 3.14147=ILS 8995=OGIS II 654). See E. A. Judge, 'Veni. Vidi. Vici, and the Inscription of Cornelius Gallus', in E.A. Judge, The First Christians in the Roman World: Augustan and New Testament Essays, ed. J. R. Harrison (Tübingen: Mohr Siebeck, 2008), 72-75.

15 E.g. Braund, Augustus to Nero, $\S \S 360,370,446,465,467,479,721$. On the ruler's control of the wealthy and the aristocrats through honours and priesthoods, see J. E. Lendon, Empire of Honour: The Art of Government in the Roman World, new ed. (Oxford: OUP, 2002), 131-39, 166-68. Concomitantly, eulogistic speeches in praise of the republican houses and their ancestral heroes, delivered at the funerals of Roman 
were signalled in the inscriptions by the adjective primus ('first'). Gallus's deliberate use of the word for his prefecture, though technically true, can only mean one thing: he locates his claim within the rhetoric of the boasting of the Roman nobiles, as the repeated use of 'first' in the Duilius inscription for his military feats over the Carthaginians demonstrates. ${ }^{16}$ The fleeting mention of Augustus's defeat of Antony and Cleopatra in $31 \mathrm{BC}$ ('after the defeat of the kings by Caesar, son of a god') is overwhelmed by the carefully tabulated list of Gallus's victories. The list adheres to the literary eulogistic convention of multiples of fives (i.e., five cities taken in fifteen days, in the case of Gallus). ${ }^{17}$ The rapidity with which Gallus's victories were accomplished is then topped by another singular accomplishment that distinguished Gallus from the rest of the commanders, a refrain also characterising the Duilius inscription: neither the Romans (including the victorious Augustus) nor the Egyptian kings had ever advanced militarily beyond the first cataract of the Nile. ${ }^{18}$ Indeed all kings, with the sole exception of prefect Gallus, feared the Thebaid. Finally, Gallus ends the inscription on a very Augustan note with the foreign kings either being subdued or seeking his protection (RG 27-33). All this stands in vast contrast to the previously restrained self-estimate of Gallus's 30 BC inscription ('chief engineer of Caesar, son of a god'), with its clear indication that the building of the Forum Julium was 'by order of Imperator Caesar'. Seemingly, in the flush of personal achievement generated by his unprecedented military victories, Gallus drew the mistaken conclusion that the traditional republican conventions of self-advertisement among the nobiles would be maintained in Augustus's principate. While acknowledging his competitor, Augustus Caesar, in the inscription, Gallus excels him by his superior accomplishments, so that Augustus slides into oblivion by

nobiles, were curtailed in the early imperial period. See V. M. Hope, Roman Death: The Dying and the Dead in Ancient Rome (London: Continuum, 2009), 78. M. B. Roller, in Constructing Autocracy: Aristocrats and Emperors in Julio-Claudian Rome (Princeton: Princeton University Press, 2001), 99-101, discusses the reduced aristocratic military activity under the Julio-Claudians.

16 Harrison, Paul and the Imperial Authorities, 223-24.

17 Judge, 'Veni. Vidi. Vici', 72.

18 Res Gestae 26.1-27.3 can be seen as Augustus's reply to careerists like Gallus who wanted to boast about the extent of their military conquest. 
contrast. However, Augustus recognised challenge to his honour early in his rule and did not let the issue slide. ${ }^{19}$

Last, another dishonour awaited the dead Gallus. In the Piazza di S. Pietro, on the foot of the so-called Vatican obelisk, is found an inscription dedicated to Augustus and Tiberius, incised in two identical versions on the eastern and western sides:

\title{
DIVO CAESARI DIVI IVLII F AVGVSTO TI CAESARI DIVI AVGVSTI F AVGVSTO SACRVM
}

Sacred

to the divine Caesar Augustus, son of the divine Julius, to Tiberius Caesar Augustus, son of the divine Augustus.

However, on the base of the obelisk was also inscribed a (now lost) inscription to Gaius Cornelius Gallus, rendered below:

\author{
[[iussu imp caesaris diui $\mathrm{f}$ \\ c cornelius cn f gallus \\ praef fabr caesaris diui $\mathrm{f}$ \\ forum iulium fecit]]
}

(vac.) [[By order of imperator Caesar, son of a god, Gaius Cornelius Gallus, son of Gnaeus (vac.), chief engineer (praef(ectus) fabr(um)) of Caesar, son of a god (vac.), (vac.) built the Forum Julium. (vac.)]]

Gallus's inscription is double bracketed to show that its bronze letters had been removed from the obelisk, leaving behind only the tell-tale holes by which the letters were orginally attached, thereby allowing F. Magi, the inscription's editor, to restore the original lettering. ${ }^{20}$ Most probably it had been removed upon the damnatio memoriae of Gallus and his subsequent suicide, though this has been challenged by J.-P. Boucher. ${ }^{21}$ The original Latin inscription of Gallus was attached to the

\footnotetext{
19 The same intolerance towards rivals is seen in the coinage of Augustus and his successors. A. Wallace-Hadrill, 'Image and Authority in the Coinage of Augustus, JRS 76 (1986), 76-87, esp. 85, highlights the spread of Augustus's head to the obverse and supplementary 'images' of imperial power on the reverse.

20 On Gallus's erased inscription, see F. Magi, 'Le iscrizioni recentemente scoperte sullobelisco vaticano', Studi Romani 11 (1963), 50-56; F. Magi, 'L'obelisco di Caio Cornelio Gallo', Capitolium 29 (1963), 488-92. See also G. Alfoldy, Der Obelisk auf dem Petersplatz in Rom: Ein historisches Monument der Antike, Sitzungsberichte der Heidelberger Akademie der Wissenschaften, phil.-hist. Klasse (Heidelburg: HAdW, 1990), not seen by me. For further discussion, see Flower, The Art of Forgetting, $125-32$.

21 Boucher, Gaius Cornélius Gallus, 56-57. Boucher points to the re-use of steles by the Egyptian pharaohs, substituting their name on the steles of their predecessors. Hence, when Caligula asked for a new obelisk for his Vatican forum, the disposable
} 
obelisk, which had been removed from Heliopolis and transported to Alexandria, ${ }^{22}$ in celebration of Gallus's building of the Forum Julium in 30 BC..$^{23}$ The obelisk in the Forum Julium was moved from Egypt in AD 37 when, as Pliny informs us (Pliny, Natural History 6:11:74; 16:40:201), Caligula relocated it to the Vatican Circus.

However, E. Iverson has convincingly challenged the likelihood that Caligula would have erected an honorific inscription to Tiberius, ${ }^{24}$ instancing (a) Caligula's strained relations with his predecessor; (b) Tiberius's exile of Caligula's mother, Agrippina Major; and (c) apart from this sole inscription, the absence of any other Caligulan inscription erected in honour of Tiberius. ${ }^{25} \mathrm{He}$ also argues that the inscription must have been dedicated to Tiberius when the ruler was

obelisk of Gallus was chosen. Yet Boucher's case has a logical flaw. Why did Gallus's obelisk remain uninscribed in Egypt for so long from $26 \mathrm{BC}$ until, as we will argue, the advent of Tiberius as ruler (AD 14-37)? Normally it would have been recycled much earlier, either for an Egyptian or Roman honorand. The fact that it was not recycled for forty years during the principate of Augustus must point to Egyptian and Augustan sensitivity regarding the dishonour to the Roman ruler that Gallus's actions had perpetrated in Egypt. Although Boucher dismisses the text (Gaius Cornélius Gallus,

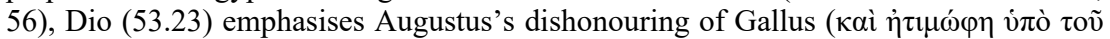

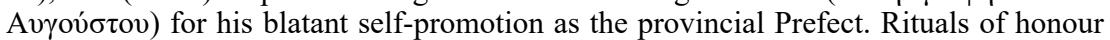
and dishonour are determinative for all the players involved in this lengthy transaction: Gallus, Augustus, the Alexandrian Egyptians, Tiberius, and Caligula.

22 F. Kayser, Recueil des inscriptions grecques et latines (non funéraires) d'Alexandrie impériales ( $I^{\text {er }}-I I I^{e}$ s. apr. J.-C.) (Cairo: Institut français d'archéologie orientale du Caire, 1994), §1, 5n2. Kayser argues that the obelisk was an Egyptian original, dedicated by Amenemhat II to the sun, from the temple of Aton at Heliopolis. By contrast, Flower (The Art of Forgetting, 313n9) speculates: 'The obelisk inscribed by Cornelius Gallus was perhaps originally intended to honour Antony.' Certainty is unachievable.

23 J. McKenzie, The Architecture of Alexandria and Egypt, c. 300 BC to $A D 700$ (New Haven, CT: Yale University Press, 2007), 79. McKenzie speculates that Gallus's erection of the Forum Iulium may have been at Nikopolis as opposed to Alexandria.

24 E. Iversen, 'The Date of the So-Called Inscription of Caligula on the Vatican Obelisk', The Journal of Egyptian Archaeology 51 (1965), 149-54, supported by Kayser, Recueil des inscriptions, §4, 23-25. Contra H. Volkmann, 'Kritische Bemerkungen zu den Inschriften des vatikanischen Obelisken', Gymnasium 74 (1967), 501-508, which argues that Caligula removed the obelisk from Nikopolis, where it had been erected, rather than from Alexandria, and that he was responsible for the inscription honouring Tiberius.

25 Iversen, 'The Date of the So-Called Inscription of Caligula', 150-51. The absence of Caligulan inscriptions honouring Tiberius is reflected in the numismatic evidence. While there are many Caligulan coins honouring the deified Augustus (H. Mattingly, Coins of the Roman Empire in the British Museum. Volume 1: Augustus to Vitellius (London: The Trustees of the British Museum, 1923), Caligula, Nos. 10, 16, 17, 24, $25,55,88-92,105-108)$, only one coin features the head of an emperor on the reverse, whose features are clearly those of Tiberius, but without an identifying legend (BMC I. Caligula, No. 1). 
still alive, since, unusually, it honours both the deified Augustus and the non-deified Tiberius (though Tiberius was never deified). ${ }^{26}$ Iverson concludes that the Egyptians, not Caligula, had honoured Tiberius at Alexandria before the obelisk was moved by Caligula to Rome. ${ }^{27}$ It is possible that this inscriptional honour was erected at the time of Tiberius's accession, legitimating the new ruler's rule by reference to his apotheosised adoptive father. But Caligula subsequently dishonoured Tiberius, in retaliation for his predecessor's behaviour towards himself and his mother, by partially erasing each of Tiberius's inscriptions on the obelisk, and by placing them in an obscured position in the Vatican Circus so that neither inscription could be seen. ${ }^{28}$

If this construction is correct, we find in both inscriptions of Gallus a remarkable portrait of the imperial rituals of dishonour from Augustus to Caligula. They stretch from Gallus's hubristic competition for honour at Augustus' expense, Augustus's reassertion of his honour by renouncing his friendship, and Caligula's deliberate sidelining of the inscriptional honours to Tiberius, accorded either by the Alexandrians or the Roman Prefect of the city, when the new Roman ruler came to power. In erecting the obelisk, Caligula not only beautified the Vatican Circus, but trumped his bete noir, Tiberius, and the hated rival of Augustus, Gallus, by erecting their honorific monument in his own building programme.

In sum, we have seen how the traditional Roman quest for glory and its concentration in the Julio-Claudian house rapidly unravelled into the same sort of self-seeking behaviour that had destroyed the Roman republic. How did Paul's understanding of 'glory' in Romans pose an alternative narrative of honour for residents living in the capital?

\subsection{Paul and the Roman Quest for Glory}

There is little doubt that Paul's language of 'glory' ( $\delta$ ' $\xi \alpha$ and cognates) in Romans draws upon the rich heritage of glory terminology in the LXX and Second Temple Judaism. ${ }^{29}$ However, in writing to the

26 Iversen, 'The Date of the So-Called Inscription of Caligula', 151-52.

27 Iversen, 'The Date of the So-Called Inscription of Caligula', 152.

28 Iversen, 'The Date of the So-Called Inscription of Caligula', 153-54.

29 Harrison, Paul and the Imperial Authorities, 232-62. On Paul's understanding of divine glory, see C. C. Newman, Paul's Glory-Christology: Tradition and Rhetoric (Leiden: Brill, 1992). 
Romans, Paul's thought engages a culture that had seen the nobiles' quest for 'glory' unravel destructively for the republic because careerists such as Cataline and Julius Caesar, so Cicero opined, had put personal fame ahead of the state, seeking 'false' instead of 'true' glory. ${ }^{30}$ Even though there was a concentration of glory in the Julian house and its successors, ${ }^{31}$ we have seen that a continuing contest for precedence had resulted in the breakdown of honour rituals, with dishonour and hatred erupting between the combatants (i.e., Gallus and Augustus; Tiberius and Caligula). Paul's theology of 'glory' was designed to convince Romans that their autonomous quest for glory was doomed because its focus was entirely wrong and dependent on human effort (Rom. 3:23). In their myopic preoccupation with ancestral fame, the Roman world had dismissed the culmination of

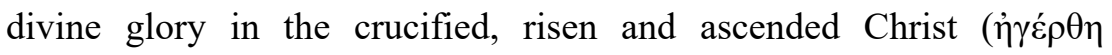
X already secured eschatological glory for believers in advance, and had transformed them in the image of Christ, the Lord of glory (Rom. 8:30; cf. 1 Cor. 2:8).

Although Paul endorses the legitimacy of the quest for glory, honour and immortality (Rom. 2:7,10), the conviction of the apostle is that the glory of God has been and continues to be dishonoured by human idolatry and ingratitude $(1: 21,23)$. In particular, this idolatrous activity (1:23b) specifically demeans the 'glory of the immortal God' (1:23a). There is no self-justifying subterfuge by which human beings can deflect the moral claims of divine glory (3:7) or claim that the participation in the covenantal glory of Israel is sufficient alone (9:4). Thus, Gallus's offerings to the ancestral gods and the Nile in recompense for his military success (1:23), the ubiquitous cult in honour of the Julio-Claudian ruler and the traditional Roman gods throughout the empire by grateful subjects $(13: 1-6,11-12 ; 1$ Cor. 8:5-6), ${ }^{32}$ and Jewish attachment to the Mosaic Law apart from its telos ('goal') in Christ (Rom. 10:4), counted for nothing.

In reality all humanity had fallen short in the quest for the glory of the immortal God (Rom. 1:23a; 3:23). In this dire situation, God brought Israel's covenantal promises to their fulfilment in Christ,

30 Harrison, Paul and the Imperial Authorities, 212-19.

31 See Harrison, Paul and the Imperial Authorities, 225-32.

32 On Paul's demotion of the Roman ruler's status, see Harrison, Paul and the Imperial Authorities, 271-323. 
resulting in the magnification of the divine glory (Rom. 6:4b; 9:23; 2 Cor. 1:22; Phil. 2:11). The glory of God, therefore, resides in Christ

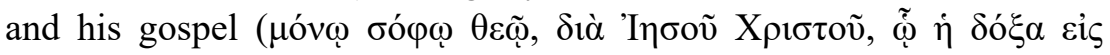
aĩ̄vas, Rom 16:27, cf. 1:1b-4, 9a, 16; 16:27; 2 Cor. 3:18; 4:4, 6). Consequently, the ancestral glory attached to the Mosaic covenant is a spent force in comparison to the new covenant of the Spirit (Rom. 7:6b; 8:4; 2 Cor. 3:7-13).

Furthermore, the resurrection age is suffused with divine glory (Rom. 6:4), with the result that suffering humanity and the groaning creation is buoyed by the eschatological hope of glory (Rom. 5:2; 8:17, 18; 2 Cor. 4:17; Eph. 1:18; Phil. 1:10-11; 3:21; 1 Thess. 2:12; 2 Thess. 1:9). Rather than life being consumed by the quest for immortality through the surpassing of ancestral honour - the obsession of the eastern Mediterranean elites and associations, ${ }^{33}$ as well as the object of heated competition by republican nobles of Rome - for Paul the eternal glory of God is the unchanging foundation of the universe and its inhabitants (Rom. 11:36; 16:27; Gal. 1:5; Eph. 3:21). Thus Paul's motivation as an apostle is not glory from men (Rom. 2:29b; 1 Thess.

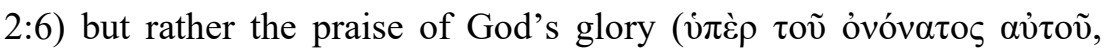
Rom. 1:5; cf. Eph. 1:6, 12, 14). This means that the exuberant concentration of 'glory' language in Augustus and his Julio-Claudian successors, at the expense of the old republican noble families, was equally misconceived.

Having set out this vision of the denouement of 'glory' in history, Paul unveils the social implications of glory in the body of Christ. Beneficence within the Body of Christ expresses thanksgiving and indebtedness to the glory of God (Rom. 15:27; 2 Cor. 4:15), with the result that the organizers of the Jerusalem collection are accorded the honorifics of glory (2 Cor. 8:19,23) and the Romans enlisted in prayer for its successful completion (Rom. 15:30-32). ${ }^{34}$ Mutual acceptance between Jew and Gentile redounds to the glory and mercy of God (Rom. 15:7, 9), assuring Paul that his sufferings as the apostle of the Gentiles are the glory of his converts (Eph. 3:13). Thus, in the present age, believers can remain confident in the glorious riches of Christ and his Spirit (Eph. 3:16), experiencing transformation into Christ's likeness from glory to glory (Rom. 8:29-30; 1 Cor. 15:43a; 2 Cor. 3:18;

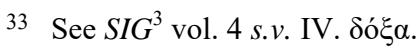

34 See Harrison, 'The Brothers as the "Glory of Christ"'. 
Phil. 3:21). In light of the glorious consummation of all things, believers need not be concerned about the loss of worldly 'honour' in service of Christ ('in honour and dishonour, in ill repute and good repute', 2 Cor. $6: 8)^{35}$, or, like their contemporaries, fear the erasure of their honour by those consumed with invidia. Indeed, Paul's greetings and commendations of Roman believers in Romans 16:1-16 establishes an alternate pattern of communal 'honour' relations in a city obsessed with the quest for honour and glory among its elites. ${ }^{36}$ Furthermore, it militates against the erasure of honour that was so ruthlessly wielded in antiquity: 'Pay to all what is due them ... respect to whom respect is

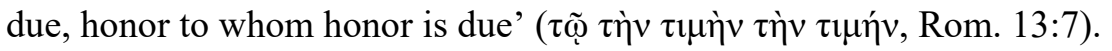

Concomitant with the heavy emphasis on the believer's transformation in divine glory through Christ is the strong rejection of 'boasting' in Romans, a theme also pertinent to the eulogistic culture of

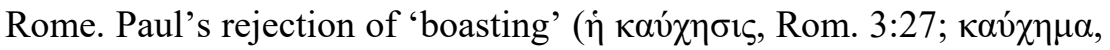
$4: 2$ ), because of the believer's justification by grace through faith in Christ, has been understood against a Jewish background, ${ }^{37}$ though 'New Perspective' scholars have isolated many examples of unilateral and covenantal understandings of grace within Second Temple Judaism, notwithstanding the residual 'merit' theologies and elements of synergism that also appear in the Jewish literature. ${ }^{38}$ What consistently is overlooked in this construct, with the exceptions of J. R. Harrison, R. Jewett and B. Kahl, ${ }^{39}$ is that Paul's rejection of 'boasting' must have had a Graeco-Roman referent as well.

Not only is this pastorally and theologically expected of the apostle to the Gentiles, but, as R. Jewett has demonstrated, ${ }^{40}$ it is grounded exegetically in the experience of God's justification of Abraham, the father of 'faith' equally for the Jews and Gentiles (Rom. 4:11-12,

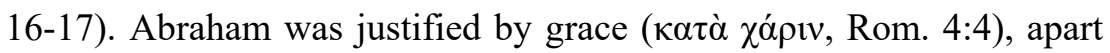
from the works of the law (Rom. 4:5-8), and significantly, at that time,

35 All translations are taken from the NRSV unless otherwise stated.

36 See J. R. Harrison, 'Augustan Rome and the Body of Christ', 31-32.

37 See S. J. Gathercole, Where Is Boasting? Early Jewish Soteriology and Paul's Response in Romans 1-5 (Grand Rapids, MI: Eerdmans, 2002).

38 J. R. Harrison, 'Paul, Theologian of Electing Grace', in Paul and His Theology: Pauline Studies Volume III, ed. S. E. Porter (Leiden: Brill, 2006), 77-108.

39 J. R. Harrison, Paul's Language of Grace in Its Graeco-Roman Context (Tübingen: Mohr Siebeck, 2003), 218-19; R. Jewett, Romans, Hermeneia (Minneapolis: Fortress, 2007), 436-37; B. Kahl, Galatians Re-Imagined: Reading with the Eyes of the Vanquished (Minneapolis: Fortress, 2010), 270-72.

40 Jewett, Romans, 309-10. 
he was not circumcised (4:9-11; cf. Gen. 15:6; 17:13-14, 21-27). Thus the question that Paul asks regarding boasting in Romans 4 had direct pertinence for the Romans: 'For if Abraham was justified by works ( $\dot{\varepsilon} \xi$

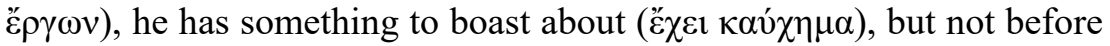
God' (4:2). The 'works' that Abraham would have boasted in, had he not been justified by God (Gen. 15:6), were Gentile works. The boasting of the Roman elites in the quest for ancestral glory, whether it were the republican nobiles or the Julio-Claudian house and their clients, was just as misguided as the Jewish quest for ancestral and divine glory through the 'works' of Law, Mosaic and oral (Gal. 1:14; Phil. 3:5-6). It simply falls short before God ( $\alpha \lambda \lambda$ ' ov̉ $\pi \rho{ }^{\prime} \varsigma$ $\theta \varepsilon o ́ v$, Rom. $4: 2 b)$. Paul's understanding of 'works', therefore, is more wide-ranging than the long-drawn debate between Reformed Theology and the New Perspective has allowed for. In discussing 'works', Paul speaks to the spiritual heart of Gentile Rome, obsessed by the pursuit of glory, as much as to covenantal Jews, highlighting for both audiences the unacceptability of human performance as a grounds of boasting before God and others (Rom. 3:27; cf. Gal. 1:14; Phil. 3:5-6; 2 Cor. 11:21b23).

Finally, Paul underscores that there is a boasting in God and the

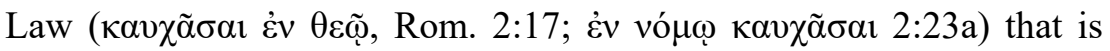
vitiated by a hypocritical disobedience to its mandates (2:22-23), thereby dishonouring God before the Gentiles (2:24). Nevertheless, Paul does not dismiss entirely the culture of boasting that was so dear to the Romans. Rather the quest for 'true' glory, to borrow Cicero's phrase, finds its culmination in Christ, the Lord of glory (8:29a; 9:23; 10:4; cf. 1 Cor. 2:8) and thus it is entirely appropriate to boast in him

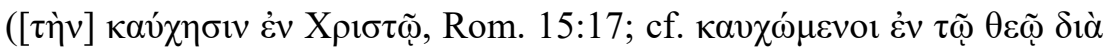

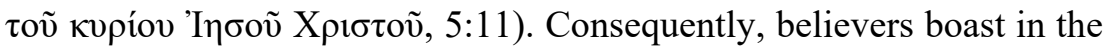

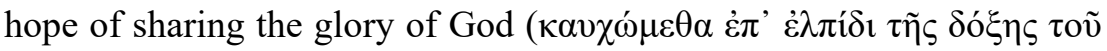
$\theta \varepsilon$ oṽ, 5:2), as well as in their tribulations on behalf of Christ

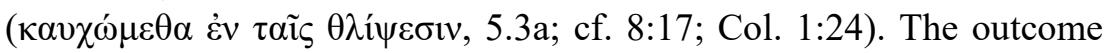
of the suffering of believers is a well-rounded character that perseveres to the end, because the Spirit produces the resilience and hope required through the indwelling love of God (Rom. 5:3b-5). In sum, Paul balances his searing critique of Graeco-Roman boasting of the 'great man' $(3: 9 b, 23,27 a$; cf. 2 Cor. 11:16-12:10) with an alternate version of divinely sanctioned boasting that culminates in honour and 
immortality for all its dependents, ${ }^{41}$ moving its focus away from the performance of powerful elites and Jewish-based nomism to the wonder of God's redemptive work through Christ in the groaning creation (Rom. 8:18-20), in the present age and in the age to come. Legitimate human boasting, therefore, places its hope in God's allocation of eschatological honour in Christ through the reign of grace rather than in the ephemeral honour of human achievement, the autonomy of which is just another disastrous expression of the reign of death (5:12-21).

In our final section we will discuss the inscription of Nikias from Isthmia which, with its erasure, affords us insight into what was at stake in terms of 'honour' and 'dishonour' in Paul's relentless attack upon rhetoric in the Corinthian epistles.

\section{Oratory at the Isthmus and the Public Competition for Honour}

\subsection{Honour and Dishonour: The Case of Nikias of Isthmia}

Inscribed on a statue base of white marble was the honorific epigram accorded to Nikias, an agonothetes, by his fellow officials, praising him for his achievements in his term of office. On the side of the same stone was inscribed an honorific decree of the Council eulogising Nikias for his ability as an orator. The statue base was found in front of a semicircular foundation at the northern edge of the Palaimonion area at Isthmia. The marble base and the bronze statue of Nikias had been later moved there from their original location in the forechamber of the Temple of Poseidon (ll. 4, 8), some $13 \mathrm{~km}$ east of ancient Corinth. Although the epigram and inscription on the marble statue base are undated, they are probably roughly contemporary with the early Roman period when the Palaimonion shrine was built (i.e., mid 1st mid 2 nd cent.). The honorific epigram on the front of the statue base (ll. 1-4) and the accompanying inscription on its side (ll. 5-15) are set out below:

41 See J. R. Harrison, 'In Quest of the Third Heaven: Paul and His Apocalyptic Imitators', VC 58.1 (2004), 24-55, esp. 46-55; J. R. Harrison, 'The Imitation of the Great Man in Antiquity: Paul's Inversion of a Cultural Icon', in Christian Origins and Greco-Roman Culture: Social and Literary Contexts for the New Testament, ed. S. E. Porter and A. W. Pitts (Leiden: Brill, 2013), 213-54. 


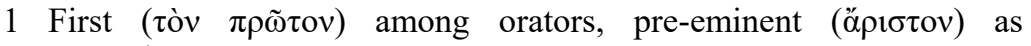
agonothetes,

Having acquired glory ( $\kappa \tilde{\delta} \delta \circ \varsigma)$ in every public office -

For these achievements your colleagues in the office of agonothetes, Erected a statue of you, Nikias, in the forechamber of Poseidon.

5 BY VOTE OF THE COUNCIL

He verily pours forth words like streams

At the mouths of ever flowing Rivers.

He stands, a portrait of bronze, before the Temple,

In the midst of pure hands, by purifying streams (of water);

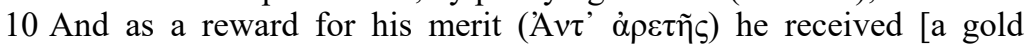
crown(?)] by which they honoured ("' $\tau \varepsilon 1 \sigma \alpha v)$ him.

Readily, unfalteringly the athlothetai knew (your worth),

O Nikias, a great delight to the city; and to the young -

Citizens and strangers alike - how great a blessing nature ("̌ $\left.\varphi \varsigma_{\varsigma}\right)$ has 15 made you. ${ }^{42}$

Broneer argues that the two honours were conveyed on separate occasions. The first (a bronze statue) was awarded for Nikias's role as agonothetes (Il. 1-4), whereas the second (a gold crown?) - the lettering of which has been deliberately erased from the stone - was awarded for his oratorical ability (Il. 6-7, 10-11)..$^{43}$ Broneer speculates what circumstances may have provoked this official censure, ${ }^{44}$ but, more importantly, the erasure shows how quickly honour rituals were supplanted by dishonour when the honorand fell out of favour. This coheres with the erasures made to the inscriptions to Gallus and Tiberius, discussed above, as well as the recycling of inscriptions against which Dio Chrysostom railed (Or. 31), violating thereby the honour of the original honorand. ${ }^{45}$

42 O. Broneer, 'Excavations at Isthmia: Fourth Campaign, 1957-1958', Hesperia 28.4 (1959), 298-343, esp. 324-26 (§5), available at http://www.ascsa.edu.gr/pdf/uploads/ hesperia/147250.pdf (accessed 18 May 2016).

43 For photos of the honorific epigram on the front and side of the statue base, see Broneer, 'Excavations at Isthmia', Plate 65, Inscription 5, Statue Base, c (picture to the left) and $d$ (picture to the right) respectively. If readers count six lines up from the bottom of the inscription, they will see that the letters in the line directly after $\check{\varepsilon} \lambda \alpha \beta \varepsilon v$ ('he received') have been deliberately erased in antiquity, indicated by the large empty space present on the stone. Broneer (325) claims there is a faint indication of the Greek letter X (chi) in the first letter space of what would have been the ensuing word,

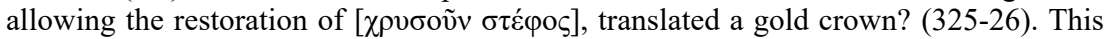
was the standard award given to honorees in the eulogistic inscriptions.

44 Broneer ('Excavations at Isthmia', 325-26) suggests that the two words were erased because Nikias did not pay the required deposit for the gold crown or because he returned the crown in a fit of displeasure in his old age. Granted the ingenuity of Broneer's suggestions, a much more likely scenario is that a jealous rival has erased the award.

45 See Harrison, 'The Brothers as the "Glory of Christ"', 170-74. 


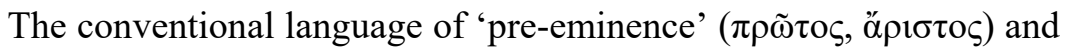
'glory' ( $\kappa \tilde{\delta} \delta \circ \varsigma$ ) is attached to the first honour (l. 1). Significantly, ceremonial hand washing occurred in a basin at the entrance of the Temple (l. 9), located just before the pronaos (an open vestibule) where Nikias's statue had originally been erected (ll. 4, 8). Nikias's reputation before posterity was thereby invested with an aura of cultic purity by virtue of its association with the sacred space and activities of the Temple. Moreover, the distinction that Nikias has achieved in an array of public offices (l. 2), including the role of agonothetes, the official who instituted the games and defrayed their expenses $(l l .1,3)$. This marks Nikias out as a socially powerful individual with (undoubtedly) inherited wealth and property, casting him in the estimation of the ancients as a man of conspicuous virtue.

In the case of the second (coronal?) honour (ll. 10-11), Nikias's oratorical power and personal worth ('a great delight to the city') is portrayed in such 'exaggerated terms' that his civic virtue ( $\dot{\alpha} \rho \varepsilon \tau \eta \dot{)})$ demands the reciprocation of honour. ${ }^{46}$ His natural virtue ("z $\left.\varphi \vee \varsigma\right)$ is apparent to all generations: the citizens and non-citizens of the city, the mature athlothetai and the aspiring young (ll. 13-15). We are witnessing the inflated moral language that dominated 'honour' discourse in the early empire. ${ }^{47}$

In sum, we have highlighted the erasure of honour on public statues and their dedications. The rarity of these occurrences needs to be underscored. The reciprocation of worthy citizens for their civic contribution had to operate with finesse in order to ensure social cohesion and the smooth operation of the honour system. In the case of Roman Corinth, for example, orators are similarly honoured in the public inscriptions: Publius Aelius Sospinus, an agonothetes (three times) like Nikias, for his 'upright character and general excellence', ${ }^{48}$ the 'good orator' Maecius Faustinus for 'his upright character', ${ }^{49}$ and

46 Broneer, 'Excavations at Isthmia', 325.

47 See A. Zuiderhoek, The Politics of Munificence in the Roman Empire: Citizens, Elites and Benefactors in Asia Minor (Cambridge: CUP, 2009), 122-28.

48 J. H. Kent, The Inscriptions 1926-1950, Corinth vol. 8 part 3 (Princeton: The American School of Classical Studies at Athens, 1966), §226 (third quarter of 2nd cent. AD).

49 Kent, Inscriptions, $\$ 264$ (mid 2nd cent. AD). Similarly, §268: [The city] by vote of the city council (erected this monument to) Marcus Valerius Taurinus, son of Marcus, [a - — - philosopher (and) a good orator] because of [his fine character]; §268: Peducaeus Cestianus the Apollonian orator. 
Poseidonius for his primacy as an orator $(\pi \rho \tilde{\omega} \tau o ́ \varsigma \tau \varepsilon \dot{\rho} \eta \dot{\tau o}[\rho]) .{ }^{50}$ While these moral accolades are entirely conventional, setting the remarkable Isthmian inscription of Nikias in even stronger relief by virtue of its florid and overstated accolades, nevertheless the Corinthian inscriptions underscore the city's obsession with rhetoric because of the precedence and moral reputation it conveyed for its practitioners, as well as the deflected glory it accrued for the sponsors of particular orators. What light do these Corinthian inscriptions eulogising orators and the Isthmian inscription of Nikias throw on rhetoric and honorific culture in the Corinthian epistles?

\subsection{Paul and the Oratorical Quest for Honour}

The Corinthian believers had been boasting in their leaders (1 Cor. $1: 12 ; 3: 4-6 ; 4: 6$ ), with some preferring those luminaries at Corinth who were, in their view, more gifted orators than Paul (o $\lambda$ ó $\grave{\varepsilon} \xi o v \theta \varepsilon v \eta \mu \varepsilon ́ v o \varsigma, 2$ Cor. 10:10b)..$^{51}$ In particular, some Corinthians preferred Apollos to their apostle (4:6b), who was professionally

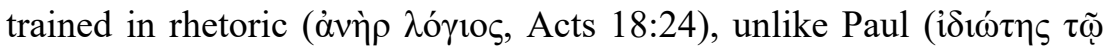
$\lambda$ ó $\gamma \omega, 2$ Cor. 11:6). ${ }^{52}$ Indeed, the apostle's lack of ability was exhibited for all to see in his 'poor' oratorical performances at Corinth $(1$ Cor. $2: 1-5 ; 2$ Cor. $10: 1 b, 10)$. The devotees of eloquence in the Corinthian house churches considered skill in rhetoric to be a sign of great wisdom and personal power, ${ }^{53}$ with the result that they had become increasingly

50 Kent, Inscriptions, $\$ 307$ (end of 2 nd cent. AD). For other orator inscriptions asserting the precedence of the honorand, see W. Dittenberger, Inscriptiones Graecae. Volume VII: Inscriptiones Megaridis et Boeotiae (Berlin: Georg Reimer, 1892), §106

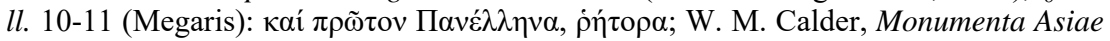
Minoris Antiqua. Volume VI: Monuments and Documents from Phrygia and Caria (Manchester: Manchester University Press, 1939), §6 List 149, 162 ll. 5-6 (Phrygia):

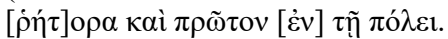

51 On Graeco-Roman rhetoric and the Corinthian Epistles, see D. Litfin, St. Paul's Theology of Proclamation: 1 Corinthians 1-4 and Greco-Roman Rhetoric (Cambridge: CUP, 1994); B. W. Winter, Philo and Paul among the Sophists (Cambridge: CUP, 1996); B. K. Peterson, Eloquence and the Proclamation of the Gospel in Corinth (Atlanta: Scholars Press, 1998); C. Mihaila, The Paul-Apollos Relationship and Paul's Stance toward Graco-Roman Rhetoric (London: T \& T Clark, 2009).

52 See P. J. Hartin, Apollos: Paul's Partner or Rival? (Collegeville, MN: Liturgical Press, 2009); Mihaila, The Paul-Apollos Relationship. However, Paul's claim to being

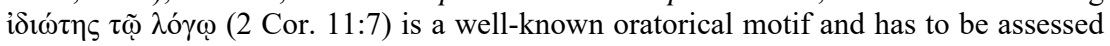
with caution as far as being an accurate indicator of Paul's rhetorical training or lack thereof. See D. B. Martin, The Corinthian Body (New Haven, CT: Yale University Press, 1995), 48-49.

53 An inscription from Iasos on a statue base honours Aulus Mussius Asper (W. Blümel, Die Inschriften von Iasos, 2 vols. [Bonn: Rudolf Habelt, 1985], §94; cf. 
arrogant (1 Cor. 4:18-20), boastful (3:21; 4:7b), self-satisfied, and, in their own estimation, 'wise' $(3: 18 ; 4: 10 \mathrm{~b})$, because of their attachment to and financial support of the leading figures in the local rhetorical celebrity circuit (9:3-18; 2 Cor. 10:12-18).

We have already noted the 'baroque' exuberance with which the pre-eminence and oratorical skills of Nikias are vaunted in his honorific decree. Dio Chrysostom (Orations 47:22) also speaks about the extravagant enthusiasm of the great cities for travelling rhetoricians in the same 'baroque' style as our inscription. What is fascinating regarding Dio's text is the fawning response of the recipients to Dio Chrysostom's visits, basking in the afterglow of the glorious visit of the great orator, as well as their financial support of him. In the responses of the eastern Mediterranean cities to Dio Chrysostom and of Isthmia to Nikias, we gain some insight into the excitement that must have been generated in some Corinthian house churches when the rhetorically gifted Apollos arrived in the city and began his teaching ministry. In this regard, some of the wealthy Corinthian converts (1 Cor. 1:26b; 11:21-22), before they became believers, may have hosted private soirees in their houses for visiting orators to the city. Now, as hosts of the house churches, they assumed that a Christian 'rhetorician' visiting in the city should be accorded the same grandiose treatment.

In response, Paul dismantles the Corinthian boasting in rhetorical accomplishment by reference to the core values of the gospel of the crucified Christ. The ignominy and shame of the crucified Christ

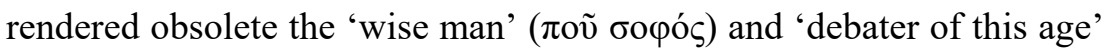

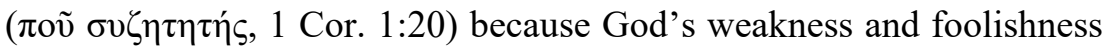
had overturned the power and wisdom of the world $(1: 17-27 ; 2: 6-7 \mathrm{a}$; $4: 20)$. The inversion of the world's values in Christ's cross $(2: 6-8)$ meant that Paul unleashed the power of the gospel by depending upon the Spirit in his preaching $(2: 4 b, 5 b, 13 b),{ }^{54}$ rather than relying upon, as was the case with the orators of the world, human eloquence $\left(\kappa \alpha \theta^{\prime}\right.$

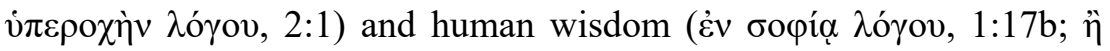

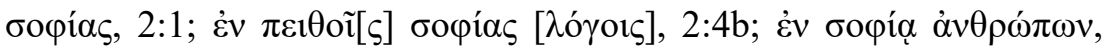

Isocrates, Oratio ad Nicolem 5-9; Cicero, De Oratione 3.53) on account of (his) most manifold and incomparable nobleness of nature in rhetoric and poetry and (in) all

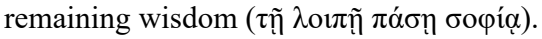

54 See T. H. Lim, "Not in Persuasive Words Of Wisdom, But in the Demonstration of the Spirit and Power"', NovT 29.2 (1987), 137-49. 
2:5b; cf. 2:6b, 13a; 3:18-19). ${ }^{55}$ The heavy emphasis on 'wisdom' terminology is particularly revealing, especially since Paul sees Christ

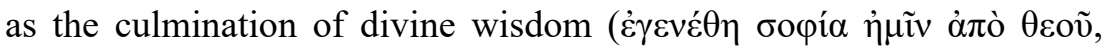
$1: 30)$.

Not only is Paul pivoting here the wisdom of the world, exemplified in rhetoric, over against the gospel traditions about the wisdom of Christ (Matt 11:19; 11:28 [Sir. 6:24-30]; 12:42; 13:54; Mark 6:2; Luke $2: 40,52: 7: 35 ; 11: 31,49 ; 21: 15)$, but the apostle is also summing up the entire Old Testament sapiental tradition in him. Wisdom, therefore, was not the preserve of the Greeks and their Corinthian acolytes (1 Cor. 1:22b; cf. 1:23-24). After Paul the presence of 'Greek' wisdom at Corinth would provoke a significant episode of dishonour for a Roman orator, the equestrian Favorinus of Arles (AD 85-c. 165; Philostratus, Vit. soph. 489-892). After his third visit to Corinth, he had his bronze statue toppled over by detractors in a damnatio memoriae (Dio Chrysostom, Or. 37:20-22). In response, Favorinus claimed that his vocation was to proclaim Greek wisdom, having so cultivated the language, thought, lifestyle and dress of the Greeks that he remained unsurpassed by Romans from the past and by Greeks in the present (Dio Chrysostom, Or. 37:25). Favorinus's mission, 'equipped by the god', was, he claimed (Dio Chrysostom, Or. 37:27), intended

for the Greeks, so that the natives of that land may have an example before them to show that culture ( $\tau$ ò $\pi \alpha \iota \delta \varepsilon v \theta \tilde{\eta} v \alpha l$ ) is not in the least inferior to birth with respect to renown; for Romans, so that not even those who are wrapped up in their own self-esteem may disregard culture ( $\tau$ ò $\pi \alpha 1 \delta \varepsilon v ́ \varepsilon \sigma \theta \alpha l$ ) with respect to real esteem; for Celts, so that no one even of the barbarians may despair of attaining the culture ( $\pi \alpha 1 \delta \varepsilon i ́ \alpha)$ of Greece when he looks upon this man. ${ }^{56}$

For Paul, however, boasting in rhetorically gifted men and the wisdom of Greek education (paideia) is illegitimate (1 Cor. 1:22b, 29, 31b; $3: 21)$. In response to the preference of some Corinthians for Apollos as an orator, Paul emphasises that he and Apollos were united in the evangelistic and pastoral mission of the gospel (1 Cor. 3:5-15). Paul's stance is that while he has primacy as the church's founding apostle

55 See S. M. Pogoloff, Logos and Sophia: The Rhetorical Situation of 1 Corinthians (Atlanta: SBL, 1992).

56 See Litfin, St. Paul's Theology of Proclamation, 144-46; B. W. Winter, 'The Toppling of Favorinus and Paul by the Corinthians', in Early Christianity and Classical Culture: Comparative Studies in Honour of Abraham J. Malherbe, ed. T. H. Olbright and L. M. White (Leiden; Brill, 2003), 291-306. 
(3:6; 4:14-20), both he and Apollos are merely God's 'servants' (3:5), with God and Christ having absolute primacy (3:6-9, 11). More

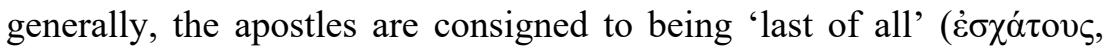
4:9), sentenced to death as one of the worthless criminals condemned to fight wild animals in the last show of the day at the amphitheatre. Paul's abdication of status pinpricks the pretentious claims of rhetoricians like Nikias ('first [ $\tau$ òv $\pi \rho \tilde{\omega} \tau o v]$ among orators') and Poseidonius ( $\pi \rho \tilde{\omega} \tau o ́ \varsigma \tau \varepsilon \dot{\rho} \tilde{\tau} \tau[\rho])$ at Isthmia and Corinth respectively. Rather than boasting in Apollos or Paul, the Corinthians should realise that diversity of gifting is what makes God's church rich and vibrant in its ministry: it is an expression of the fact that all things are ours in Christ and God (3:21-23).

Last, we turn to the issue of the erasure of coronal (?) honour in the inscription of Nikias. Assuming that Broneer's restoration is correct, we see the force of Paul's assertion that coronal awards of honorific culture are 'perishable' ( $\varphi \theta \alpha \rho \tau$ òv $\sigma \tau \varepsilon \dot{\varepsilon} \varphi \alpha v o v, 1$ Cor. 9:25), even if Paul's imagery in this instance is drawn from the Isthmian games as opposed to the civic arena. Coronal awards belong to the world that is 'passing away' (7:31) and therefore Paul delays the award of 'imperishable crown' until the eschaton ( $\alpha \varphi \theta \alpha \rho \tau o v, 1$ Cor. 9:25b). ${ }^{57}$ But the believer's distinction - founded on Christ's imputed 'righteousness' (2 Cor. 5:21 [cf. 1 Cor 1:30]; Phil. 3:9) - will not be erased: God will come to their eschatological defense (Rom. 8:33) and allocate their crown (1 Cor. 9:25b; Phil. 4:1; 1 Thess. 2:19; cf. 2 Tim. 4:8). In the present, however, while honorific culture has its legitimate place (Rom. 13:7b), Paul inverts the social hierarchy of honorific accolades, extending them from the most respectable to, in God's vast social reordering, the least respectable, weakest, and inferior within the Body of Christ (1 Cor. 12:22-25). Finally, in contrast to the intense fear of the erasure of honour in the ancient world, for Paul the experience of 'honour' and 'dishonour' are simply two different experiences of legitimate and praiseworthy service of Christ (2 Cor. 6:8). The difference between the social worlds of Nikias and Paul could not be further apart.

57 See J. R. Harrison, “"The Fading Crown": Divine Honour and the Early Christians', JTS 54.2 (2003), 493-529; J. R Harrison, 'Paul and the Athletic Ideal in Antiquity: A Case Study in Wrestling with Word and Image', in Paul's World, vol. 4 of Pauline Studies, ed. S. E. Porter (Leiden: Brill, 2007), 81-109. 


\section{Conclusion}

In this article we have explored the little-studied phenomenon of the erasure of distinction in the honorific inscriptions by concentrating on two epigraphic case studies, one drawn from the Latin West and the other from the Greek East. This formidable convention of the public erasure of an individual's honour - arising from amicitiam renuntiare or damnatio memoria, or from the invidia of civic and family rivals, or from the malice of influential enemies - has thrown light on the fear that civic dishonour held for the elites and their clients. Some in the city-states of Alexandria, Rome, Athens, and Isthmia would have been enthralled by the extinction of fame of the powerful at the hands of their enemies, and, very rarely, by its pious resuscitation at the hands of their supporters.

What we do not know is the reaction of those at the base of the social pyramid to extinctions of fame and their occasional resuscitations. The silence is revealing: their reaction was an irrelevance because they belonged to the dishonourable members of the body politic. As far as the old elites of Rome, however, the traditional quest for glory, ancestral and personal, was now summed up in the Julio-Claudian house. The future for the elites and other aspirants to social status in the capital lay in the pathways of upward mobility that the imperial bureaucracy and the Roman army had opened up throughout the empire, but without inordinately boasting in one's achievements at the expense of the ruler's honour. This was the lesson that Gallus failed to learn.

By contrast, the acquisition of wisdom and virtue by oratorical precedence and the achievement of civic magistracies through the inherited wealth and property - both exemplified in the career of Nikias - were still the core values of the hierarchical society in the eastern Mediterranean city-states. These values shaped the pathways of honour for the educated and affluent at the level of civic magistracies and in the clientage networks of Roman provincial rule and the imperial cult. This social construct was sometimes fragile, with the potential of debilitating dishonour lurking below the surface, as the sudden and unexplained reversal experienced by Nikias testifies.

What is intriguing is that Paul constructs an alternate model for the acquisition of honour that is diametrically opposed to this system, extending honour rituals from the base of the social pyramid to its apex 
rather than the reverse, as was the case in the Graeco-Roman world. ${ }^{58}$ The apostle enunciates the rationale for this inversion of honour. The

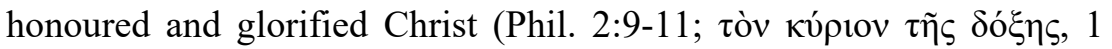
Cor. 2:8) had suffered total dishonour in his crucifixion (1 Cor. 1:23; 2:8; Gal. 3:13; 5:11b; Phil. 2:7-8), leaving aside the glory of his heavenly riches and assuming the impoverishment of broken humanity (2 Cor. 8:9; Phil. 2:6). Moreover, God had chosen the socially despised and powerless to be the mainstay of his eschatological community in order to shame the wise and the strong (1 Cor. 1:26-28). Furthermore, God had deliberately structured the Body of Christ so that the greater

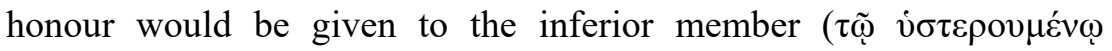

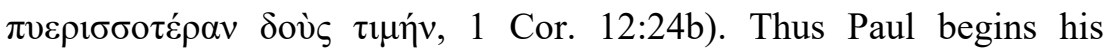
thinking about the outworking of honour rituals at the very bottom of the social hierarchy: he highlights for believers the paradigm of Christ's incarnational self-lowering and self-emptying; he underscores the numbing shock of Christ's humiliation on the cross, given his exalted pre-incarnate status (Phil. 2:6, 8b); and, last, he points to God's unexpected choice of the dishonoured over the honoured as his children.

Consequently, believers were to outdo each other in giving honour

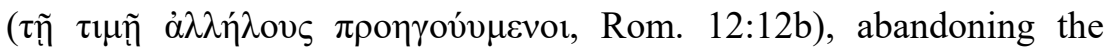
heated Graeco-Roman competition for personal honour with its catastrophic repercussions of dishonour, choosing instead to associate with the lowly ( $\dot{\alpha} \lambda \lambda \grave{\alpha} \tau o i \tilde{\varsigma} \tau \alpha \pi \varepsilon 1 v o i ̄ \varsigma ~ \sigma o v \alpha \pi \alpha \gamma o ́ \mu \varepsilon v o 1,12: 16 \mathrm{~b})$. But this was to be done without omitting to honour the high status individuals at the apex of the social pyramid to whom honour was legitimately due

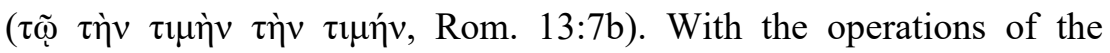
honour system thus redefined in social relations, Paul addresses the rituals of the awarding of honour. The acquisition and allocation of glory and virtue in the quest for immortality (Rom. 2:7, 10) was entirely the prerogative of God (3:22b-26). Although the believers' eschatological glory is secured in advance because of Christ's salvation enrichment of his dependents (Rom. 8:30), it is only fully allocated at

58 Lower social echelon members gained honour outside traditional pathways through the local associations and, in some cases, as members of the familia Caesaris. See Harrison, 'Paul and Ancient Civic Ethics'; G. H. R. Horsley, 'Joining Caesar's Household', New Docs 3 (1983), 7-9. Dio Chrysostom (Or. 34.51) speaks of 'fellow slaves wrangling with one another over glory and precedence' in the imperial household. 
the eschaton when each believer is crowned at Christ's parousia to the glory of God (Phil. 3:21-4:1; cf. 2 Tim. 4:8). In the interim period, however, Paul views the believer's experience of honour and dishonour as the inexorable expression of faithful discipleship in waiting for the Kingdom (2 Cor. 6:4, 8). In sum, by means of his theology of the incarnation, the cross and divine election, Paul turned the 'politics of dishonour' on its head. 